\title{
МОНІТОРИНГ ХВОРОБ ШКІРИ СОБАК В УМОВАХ ПРИВАТНОЇ ВЕТЕРИНАРНОЇ КЛІНІКИ «АЛЬФА-ВЕТ», М. КОНОТОП
}

Стоцька Ольга Ігорівна аспірант

Сумський національний аграрний університет (м. Суми, Україна) ORCID: 0000-0003-4469-1539, stotska.olga@gmail.com

В роботі був проведений моніторинг захворюваності собак на дерматити поліетіологічного походження. Дерматит - загальне визначення для будь-якого типу запалення шкіри. Цей термін, зазвичай, використовують для опису стану шкіри до досягнення конкретного діагнозу. Існує безліч причин запалення шкіри, включаючи зовнішні подразники, опіки, алергени, травми та інфрекції (бактеріальні, вірусні, паразитарні або грибкові). Дерматит також може бути пов'язаний із захворюваннями внутрішніх органів

Дослідження проводилися на базі клініки ветеринарної медицини «Альфра -вет» (м. Конотоп, вул. Красногірська 4а) в період 2020-2021 рр. Пацієнтами для проведення досліджень були хворі на дерматити собаки порід мопс, ягд-тер'єр, лабрадор, стафордширський тер'єр, німецька вівчарка, шарпей, такса, французький бульдог, різних вікових груп та статі.

Всього клінічно за цей період було обстежено 730 собак. При постановки діагнозу враховували дані анамнезу, клінічні ознаки, результати мікроскопічних досліджень, клінічні та біохімічні показники крові, цитологічні дослідження.

Саркоптичний дерматит був зареєстрований у восьми випадках, в яких, крім саркоптичних кліщів, також були помічені нейтрофріли, макрофаги та плазматичні клітини та ороговілі епітеліальні клітини. Гематологічними дослідженнями встановлена відносну нейтрофрілія та легка еозинофрілію. Важкого та генералізованого демодекозу, ускладненого бактеріями та Malassezia sp. також було зафіксовано у 28 випадках зараження. Гістопатологічно численні Demodex sp. було виявлено клішів у різній стадії дозрівання, які пошкоджують волосяні фролікули разом із супутніми патологічними змінами та гранулемами стороннього тіла. Крім того, алергічний дерматит від бліх також спостерігався у 89 собак. Цитологія виявилася однозначно ефективною при діагностиці паразитарного дерматиту.

Собак з атопічним дерматитом було зафріксовано 28 випадків. Однак виникнення нових випадків постійно зростає. Патогенетичні механізми цього захворювання до кіния не вивчені, проте доведено участь аномальних генів та змінених імунологічних процесів. У собак діагноз атопічного дерматиту грунтується на зборі анамнезу, клінічному обстеженні та диференційній діагностиці. Основну частину захворювань займають алергічні хвороби шкіри та бактеріальні захворювання шкіри собак.

При проведенні моніторингу дерматитів у собак було встановлено, що алергічні дерматити складали 63,01 \% випадків; паразитарні - 24,66 \%, грибкові - 9,32 \% та бактеріальні - 3,01\%

Найбільш складні у діагностуванні та лікуванні атопічний, контактний та алергічний дерматити.

Ключові слова: дерматит, саркоптоз, демодекоз, цитологія, атопічний дерматит, алергія.

DOI https://doi.org/10.32845/bsnau.vet.2021.2.1

Вступ. Шкіра будучи зовнішньою оболонкою вкриває все тіло тварини і складається з трьох шарів: епідермісу (надшкір'я), основи шкіри і (власне шкіри) та підшкірного шару.

Функція шкіри в організмі різнобічна і включає в себе захист організму від впливу фізичних, хімічних і біологічних подразників та від висихання. Крім того шкіра тварин будучи фізичним бар'єром, не дозволяє шкідливим агентам проникати в організм. У шкірі та на її поверхні $€$ ще й хімічний бар'єр. Кисла реакція поверхні шкіри (рН близько 6,0) гальмує розвиток патогенних мікробів.

Шкіра собаки діє як бар'єр, що відділяє його внутрішні органи, м'язи та скелет від навколишнього середовища. Крім того шкіра запобігає втраті води, знижує ймовірність зневоднення та допомагає регулювати температуру тіла. Таким чином, шкіра собаки - це важливий фільтр між навколишнім середовищем та його тілом, який потребує належного догляду.

Також важливою функцією шкіри є захист від паразитів, в ній накопичуються жири, вода та вітаміни, а також містить чутливі нервові закінчення.
Останнім часом хвороби шкіри у собак займають одне з чільних місць серед хвороб, які можуть визначатися за станом шкіри багатьма власниками тварин, як досвідченими, так і початківцями, та визначати стан здоров'я свого вихованця.

Неправильне харчування, захворювання серцево-судинної системи, гіповітамінози, гормональний дисбаланс та значна кількість інших захворювань можуть проявляти негативний вплив на шкірні покриви собак.

Серед захворювань шкіри певна їх частина лікується досить просто, але діагностика таких захворювань та боротьба з ними займає масу часу та спричиняє значні фінансові затрати.

Аналіз останніх досліджень та публікацій.

Хвороби шкіри у собак займають одне з чільних місць у структурі захворювань різного генезису і незважаючи на останні публікації залишається актуальним питанням, та потребує подальшого вивчення патогенезу, причин виникнення яке постійно досліджується ветеринарними лікарями. Серед хвороб шкіри чільне місце займають екземи та дерматити. 
Екзема - запалення поверхневих шарів шкіри, що характеризується поліморфізмом висипів та схильністю до рецидивів та є одним з найбільш частих захворювань шкіри у собак. Вказується, що основна причина подразнення певних ділянок епідермісу, пилом, хімічними речовинами, паразитами, бактеріями. Процес зазвичай супроводжується переходом запального процесу на глибокі шари шкіри. Захворювання частіше діагностується у собак, але зустрічається і у кішок. Слід відмітити, що найбільш схильними до екземи є породи з густим підшерстям, яскраво вираженими шкірними складками та тварини старших вікових груп.

Екзема як і багато інших захворювань шкіри, досить часто виникає на тлі ослабленого організму. Вказується, що серед фракторів, що викликають недугу є: надмірно суха або, навпаки, волога шкіра; гормональні порушення; неправильне харчування; алергії; патології імунітету; емоційні навантаження і стреси; хвороби шлунково-кишкового тракту, печінки, нирок, нервової системи; недостатній або надмірний догляд.

Екзема у собак здебільшого ділиться на три види: невропатична, травматична та рефлекторна.

Невропатична екзема $є$ реакцієюя шкіри на вегетативні розлади, внаслідок перенесення хвороби або як $€$ вродженим недугом і локалізується на зовнішній стороні стегон або уздовж хребта.

Травматична екзема виникає на фоні травми та пошкодження епідермісу, наприклад за тривалого використання незручного нашийника. Іншою причиною екземи бувають опіки чи відмороження, відсутність обробки антисептиками місць укусів комахами, паразитами.

Рефлекторну екзема як реакцію шкіри на подразник можуть спонукати зовнішні подразники: бруд, паразити, хімічні речовини; внутрішні - алергени, гельмінти, збої в організмі (гормональні або обмінні).

Розповсюдження запалення на глибокі шари шкіри зумовлює дерматити.

Дерматит - загальне визначення для будь-якого типу запалення шкіри, причин якого існує безліч та включає як зовнішні подразники, опіки, алергени, травми та інфекції (бактеріальні, вірусні, паразитарні або грибкові), так і може бути пов'язане із захворюваннями внутрішніх органів.

Дерматити різного походження становлять значну частину серед захворювань шкіри у собак.

Серед них в деяких зонах домінують паразитарні дерматити, які поділяють на: сифункулятоз, саркоптоз, отодектоз та демодекоз.

Слід відмітити, що ураження шкіри, спричинене блохами є найпоширеніша дерматологічною патологіє дрібних тварин у більшості країн світу.

Збудником хвороби у собак є блоха Ctenocephalides canis, яка швидко розмножується у теплому та вологому навколишньому середовищі, у густому підпушку, за температури від 18 до 30 градусів та відносній вологості 70-80 \% (Pfister, K., Armstrong, R., 2016).

Збудником саркоптозу є дрібні кліщі Sarcoptes scabiei var. canis, розмір яких становить 0,2-0,5 мм. Собака $€$ специфічним господарем, але носіями можуть бути коти, а в дикій природі лисиці. Реєструються випадки коли кліщ може посилитися і на людині, зумовлюючи інтенсивний свербіж.

Також досить частою у собак $є$ вушна короста (отодектоз) - інвазивне захворювання собак та інших м'ясоїдних викликається паразитуванням в зовнішньому слуховому проході і внутрішній поверхні вушних раковин кліщів Otodectes cynotis родини Psoroptidae.

Захворювання супроводжується свербінням, розвитком дерматиту та отиту. Ускладнюючим фактором є секундарна бактерійна та грибкова мікрофрлора: Malassezia pachydermatis, бактерій Pseudomonas aeruginosa, Proteus spp., Staphylococcus spp. i Streptococcus spp.

Доки у вушному каналі виділення не накопичилися, найбільше кліщів збирається в районі барабанної перетинки, що можна побачити за допомогою отоскопа. Вторинне зараження бактеріями і дріжджовим грибком можна виявити за допомогою бак посіву (Taenzler et al., 2017).

Кліщ Demodex canis частина нормальної мікрофлори шкіри та у невеликій кількості присутній у більшості здорових собак, перебуваючи у волосяній цибулині, рідше - у сальних залозах, харчуючись клітинами, жиром та епідермальним злущенням тканин. Новонароджені цуценята заражаються від матері.

Волосяний кліщ або ж фолікулярний демодекоз - це паразитарна хвороба собак, зумовлена масовим розмноженням кліщів Demodex, зумовлюючи запалення волосяних цибулин та сальних залоз, за ймовірного розмноження кліщів внаслідок генетичних чи імунологічних порушень в організмі тварини (Nashat et al., 2018).

Алергічними захворюваннями шкіри у собак є запалення внаслідок алергії на слину бліх; атопічний дерматит; харчова алергія та контактний дерматит.

Запальний процес з алопеціями внаслідок алергії на слину бліх здебільшого локалізується в попереково крижовому відділі у собак. При обстеженні легко виявляються кілька бліх які активно рухаються між волоссям.

Блошиний алергічний дерматит - це реакція підвищеної чутливості на протеолітичні ферменти та гістаміноподібні речовини, що містяться в слині бліх. Цитологічно мазки, зроблені зі зіскрібків уражених місць, мають негативний результат на наявність кліщів і грибки. Характерно, що дослідники помітили кілька еозинофілів, епітеліальних клітин та нейтрофрілів. Вчені довели, що діагностична цитологія $€$ ефективною методикою діагностики паразитарного дерматиту на рівні з асоційованою запальною реакцією отже, може бути використана як альтернатива звичайним методам зрізання шкіри та гістопатології (Shannon, Bosio \& Hinnebusch, 2015).

Атопічний дерматит також поширене шкірне захворювання у собак. Його клінічні, імунологічні, гістологічні та патологічні особливості у собак настільки схожі з аналогами людини, що собачий атопічний дерматит був запропонований як тваринна модель для атопічного дерматиту людини. Атопія - це неадекватна відповідь імунної системи (негайна надчутлива алергічна реакція), сформована успадкованою генетичною схильністю і певними факторами довкілля, і яка найчастіше супроводжується виробленням алерген-специфічних антитіл типу $\mathrm{lgE}$. 
У собак ознаки в першу чергу проявляються на шкірі, але алергічна реакція може проявитися і на слизових оболонках і в органах дихання. У собак виділяють генетичну схильність породи: німецька вівчарка, ретривери, бульдоги, тер'єри, боксер, мопс (Schwingen et al., 2020).

Значний відсоток виявлення харчової алергії спостерігається у тварин до 1 року. Гіперчутливість до компонентів корму викликає прояви на шкірі, але поруч із цим у 15-20\% собак, що страждають на харчову алергію, виникають проблеми зі шлунково-кишковим трактом. Харчову алергію собак найчастіше спричиняють білки курячого м'яса, але також часто спостерігається алергічна реакція на білки яєць, яловичини, молока та молокопродуктів, зернові білки. Харчова алергія клінічно проявляється - несезонним, періодичним, рецидивуючим свербежем. Клінічні прояви аналогічні проявам при атопічному дерматиті, але позитивна реакція на глюкокортикоїдну терапію менша. Елімінаційні дієти часто містять білки і пептиди з низькою молекулярною вагою, що виникають в результаті ферментативного перетравлення (гідролізу) білків з вихідних матеріалів (Bizikova \& Olivry, 2016). Дієти з гідролізованим білком вважаються терапевтичними для домашніх тварин, оскільки вони можуть запобігти алергічні реакції з-за харчової гіперчутливості. У людей IgE може розпізнавати білкові алергени з молекулярної масою від 5 до 50 кДа, тому гідролізовані білки в елімінаційних дієтах повинні мати молекулярну масу нижче 5 кДа, щоб запобігти алергічні реакції (Olivry, Bexley \& Mougeot, 2017). Недавнє дослідження на собаках показало, що собачий раціон, приготований з гідролизованого борошна з пташиного пір'я, що містить 95\% гідролізованих білків з молекулярною масою $\leq 1$ кДа, не викликав клінічних реакцій ні в однієї з собак, які страждають алергією на курку. Однак інший раціон, що містить 78\% гідролізованих білків курячої печінки з молекулярної масою $\leq 1$ кДа, дійсно викликав алергічні реакції y $40 \%$ собак. (Masuda et al., 2020).

Контактний дерматит - це гіперчутливість уповільненого типу, що виникає внаслідок контакту алергену, що прорвався між чутливими особами. Ця хвороба фактично опосередковується клітинами Т-лімфоцитів, поєднання сенсибілізованого Т-лімфоцита та відповідного зв'язування антигену призводить до активації вивільнення різноманітних цитокінів, утворюючи запальну дію, що характеризується інфільтрацією моноцитів та дегенерацією тканин (Kwon et al., 2021).

До бактеріальних захворювань шкіри відносять: піодермію, маласезійний дерматит, абсцес, трихофітію та мікроспорія.

Піодермія або гнійне запалення шкіри - це бактеріальне ураження (епідермісу, дерми підшкірної клітковини та похідних шкіри, включаючи волосяні фолікули і сальні залози) яке викликається гнійними бактеріями. В даний час в Японії (від поверхневої піодермії собак часто виділяють стійкі до протимікробних препаратів стафілококи, особливо стійкий до метициліну Staphylococcus pseudintermedius (MRSP). Однак мало що відомо про носової поширеності MRSP у домашніх собак. Тому дослідники визначили поширеність стійких до протимі- кробних препаратів стафрілококів в ніздрях і уражених ділянках домашніх собак з поверхневою піодермією. 3125 ніздрів і 108 уражених ділянок домашніх собак з поверхневою піодермією були виділені 107 (13 видів) і 110 (вісім видів) штамів стафілококів відповідно. Частота виділення S. pseudintermedius з ділянок піодермії (82/110 штамів, 74,5\%) була значно вищою, ніж з ніздрів (57/107 штамів, 53,3\%) (P <0,01). Примітно, що поширеність MRSP (18/57 штамів, 31,6\%) в ніздрях була еквівалентна поширеності в місцях розташування піодермії (28/82 штамів, 34,1\%). Крім того, фенотип і генотип стійкості до протимікробних препаратів в штамах MRSP 3 ніздрів були аналогічні таким 3 ділянок піодермії. Результати показали, що поширеність стійких до протимікробних препаратів стафілококів в ніздрях домашніх собак з поверхневою піодермією знаходиться на тому ж рівні, що і в уражених ділянках (Nakaminami et al., 2021).

Мета. У зв'язку з цим метою роботи було вивчення розповсюдження хвороб шкіри у собак в умовах приватної ветеринарної клініки «Альфа-вет» (м. Конотоп).

Матеріали та методи дослідження. Дослідження проводилися в умовах клініки ветеринарної медицини «Альфа-вет» (м. Конотоп) на протязі чотирьох сезонів року у період з 1 квітня 2020 року до 1 квітня 2021 року.

Собаки, у яких при надходженні до клініки були ознаки враження шкіри підлягали детальному обстеженню для встановлення нозологічної форми захворювання.

За заначений період нами було діагностовано захворювання шкіри у 730 собак, порід - мопс, ягдтер'єр, лабрадор, стафордширський тер'єр, німецька вівчарка, шарпей, такса, фрранцузький бульдог, різних вікових груп та статі.

При постановці діагнозу враховували дані анамнезу, клінічні ознаки, результати мікроскопічних досліджень, клінічні та біохімічні показники сироватки крові, цитологічні дослідження.

Результати дослідження. Проведеними дослідженнями встановлена наступна структура захворювань шкіри (табл. 1).

Як видно з даних представлених в таблиці структура хвороб шкіри у собак є неоднорідною і може змінюватися від пори року.

За досліджуваний період нами діагностовано 730 випадків хвороб шкіри зумовлені різними етіологічними чинниками.

Так, найбільший відсоток хвороб шкіри у собак були пов'язані з алергією і становили більш 60 \% випадків, при цьому більше 40 \% це харчова алергія.

В меншій мірі діагностувався блошиний алергічний дерматит 89 випадків, контактний та атопічний дерматити, 5,07 і 3,84\%, відповідно.

Слід зазначити, що майже $25 \%$ становили хвороби шкіри спричинені паразитами, серед яких виділялись тварини хворі на сифункулятоз, майже $15 \%$, доля тварин хворих на отодектоз становила майже 5\%, на демодекоз менше на один відсоток від попереднього показника, і 1,1\% випадків діагностувавася саркоптоз.

Діагноз на паразитарні хвороби шкіри нами був підтверджений мікроскопічними дослідженнями виділень 
з вушного каналу, що давало можливість в подальшому розробити та запропонувати схему лікування.

В межах $10 \%$ у випадків у собак діагностувалися грибкові захворювання шкіри, мікроспорія та трихофітія майже 7,5\%, маласезійний дерматит зумовлений грибом виду Malassezia 14 випадків.

Слід відмітити, що найменший відсоток хвороб шкіри у обстежених тварин було зумовлено, бактеріями, становлячи лише 3,01 \% від загальної кількості хворих, при цьому менше 1\% становили хворих тварин мали діагноз піодермія, і більше $2 \%$ становили абсцеси.

Таблиця 1

Структура хвороб шкіри у собак в умовах приватної ветеринарної клініки «Альфа-вет» (м. Конотоп) за досліджуваний період

\begin{tabular}{|c|c|c|c|}
\hline \multicolumn{4}{|c|}{ Шкірні хвороби собак, спричинені паразитами } \\
\hline & \multicolumn{2}{|c|}{ гол } & $\%$ \\
\hline отодектоз & \multicolumn{2}{|c|}{36} & 4,93 \\
\hline саркоптоз & \multicolumn{2}{|c|}{8} & 1,10 \\
\hline демодекоз & \multicolumn{2}{|c|}{28} & 3,84 \\
\hline сифункулятоз & \multicolumn{2}{|c|}{108} & 14,79 \\
\hline всього & \multicolumn{2}{|c|}{180} & 24,66 \\
\hline \multicolumn{4}{|c|}{ грибкові захворювання шкіри } \\
\hline $\begin{array}{c}\text { мікроспорія } \\
\text { та трихофітія }\end{array}$ & \multicolumn{2}{|c|}{54} & 7,40 \\
\hline $\begin{array}{c}\text { маласезійний } \\
\text { дерматит }\end{array}$ & \multicolumn{2}{|c|}{14} & 1,92 \\
\hline всього & \multicolumn{2}{|c|}{68} & 9,32 \\
\hline \multicolumn{4}{|c|}{ алергічні шкірні хвороби собак } \\
\hline $\begin{array}{l}\text { атопічний } \\
\text { дерматит }\end{array}$ & \multicolumn{2}{|c|}{28} & 3,84 \\
\hline $\begin{array}{c}\text { харчова } \\
\text { алергія }\end{array}$ & \multicolumn{2}{|c|}{306} & 41,92 \\
\hline $\begin{array}{c}\text { блошиний } \\
\text { алергічний } \\
\text { дерматит }\end{array}$ & \multicolumn{2}{|c|}{89} & 12,19 \\
\hline $\begin{array}{c}\text { контактний } \\
\text { дерматит }\end{array}$ & \multicolumn{2}{|c|}{37} & 5,07 \\
\hline всього & \multicolumn{2}{|c|}{460} & 63,01 \\
\hline \multicolumn{4}{|c|}{ бактеріальні захворювання шкіри } \\
\hline \multicolumn{2}{|c|}{ піодермія } & 7 & 0,96 \\
\hline \multicolumn{2}{|c|}{ абсцес } & 15 & 2,05 \\
\hline \multicolumn{2}{|c|}{ всього } & 22 & 3,01 \\
\hline \multicolumn{2}{|c|}{ Всього хвороб шкіри } & 730 & 100 \\
\hline
\end{tabular}

Таким чином, проведеними дослідженнями встановлено, що структура хвороб шкіри не є сталим показником а може змінюватися в залежності від багатьох фракторів як зовнішнього так і внутрішнього середовища.

При проведення аналізу сезонної динаміки хвороб шкіри у собак в умовах приватної ветеринарної клініки «Альфа-вет» (м. Конотоп) встановлено, що на виникнення хвороб шкіри має пора року.

Так, більшість захворювання діагностувалося у весняно - літній період, і ймовірно пов'язаний зі зниженням резистентності організму собак.

Наприклад, демодекоз у собак діагностувався частіше у віці 1-4 роки, різної статі та породи.

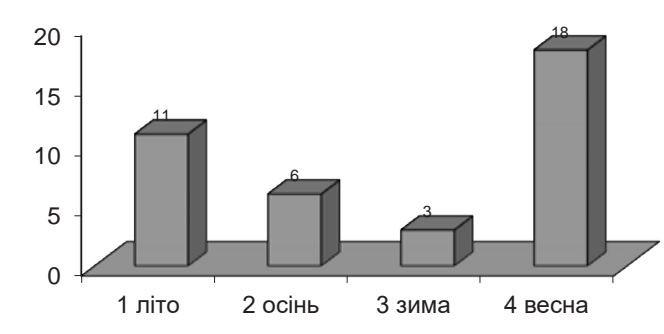

Рис. 1. Сезонна динаміка демодекозу у собак

При встановлені діагнозу суттєва роль належить мікроскопічному дослідження зіскрібків, анамнестичним даним, характерним клінічним ознакам хвороби.

3730 загальних випадків дерматиту 8 (1,1\%) випадків саркоптичного дерматиту були діагностовані та підтверджені мікроскопічним дослідженням зіскрібків. Наявність декількох кліщів на різних стадіях розвитку була основою діагностики у всіх випадках. Випадки спостерігались у семи собак-самців та однієї суки різних порід віком від 1 місяця до 10 років.

При вивченні вікової поширеності саркоптозу встановлено, що собаки віком до 6 місяців (сім випадків) були більш сприйнятливими. Загалом ураження варіювали від папул до струпів, розподілених в різних частинах тіла лікоть, гомілка, живіт і кінцівки. Ураження, локалізовані на ліктьовому суглобі, кістці та кінцівках, мали тенденцію утворювати струпи, тоді як ураження живота були папульозними до гнійничкових висипань. Це може бути пов'язано з недоступністю місць для подряпин собаками. У всіх випадках спостерігався сильний свербіж, еритема, зроговіння, екскоріація та поганий стан волосся. Найбільш ефективний та надійним в умовах клініки є метод «diagnosis ex juvantibus», тобто - лікування акарицидними препаратами, внаслідок чого тварина видужує. Також як додаткова терапія використовуються шампуні від себореї у склад якої входить 4\% Хлоргексидину.

Чим більше критеріїв маємо, тим більш специфічний діагноз.

Так, харчова алергія мала найбільші показники 306 випадків була зумовлена гіперчутливістю до компонентів корму. Оскільки багато інших проблем можуть викликати подібні симптоми, і собаки можуть страждати не тільки від харчової алергії, дуже важливо було щоб усі інші проблеми були ідентифіковані. Атопія, алергія на укуси бліх, гіперчутливість до кишкових паразитів, саркоптоз і грибкові та бактеріальні інфекції - все це може викликати симптоми, подібні до харчової алергії. Після диференційної діагностики виключали алергени із раціону харчування, проводили постійну проти блошину терапію і проводили лікування вторинних інфекцій.

Контактний дерматит діагностувався у 37 випадків. У патогенезі захворювання його у собак виділяють прямий контакт з квітковим пилком, матеріалами рослинного, тваринного чи штучного походження, фрарба, засоби для очищення, мило, шампунь, здатних викликати алергічну реакцію. Клінічні прояви - еритеми, макули, папули, свербіж, вторинна бактеріальна інфекція та її ознаки. 
Таким чином, у етіології захворювань шкіри переважають випадки алергічних дерматитів.

Обговорення та інтерпретація проведеного дослідження, порівняння 3 дослідженнями інших вчених. Протягом останніх десятиліть різні особливості патогенезу алергічного дерматиту були висвітлені шляхом зосередження уваги або на централізованої точки зору вродженої імунної системи, або на більш помітну роль Т-хелперних клітин, що фокусується на поляризації Th1 (Mucha et al., 2020). Остання точка зору виникла 3 моделей ксенотрансплантатів, в яких стимульовані лімфоцити були необхідні для індукції псоріазоподібні фенотипу, що суперечить ролі однієї тільки вродженої імунної системи (Norsgaard et al., 2012). Відповідно до цього аберрантним функціональність Т-клітин призводить до атипового цитокінового середовища в ураженій ділянці шкіри.

Питання про те, чи є псоріаз результатом дисфункціональних вроджених властивостей імунних клітин, все ще обговорюється. У тематичних дослідженнях, які аргументують цю гіпотезу, повідомляється про розчиненність псоріатичних бляшок після трансплантації алогенних стовбурових клітин. Це також підтверджується дослідженнями ролі гемопоетичних стовбурових клітин при псоріазі (Swindell et al., 2013). Кератиноцитам відводилася не пасивна роль в цій концепції, відповідаючи гіперпроліферацією, порушенням диференціювання та вивільненням прозапальних цитокінів прямої дії. Однак для діагностики алергічного дерматиту важливий змішаний адаптивний прояв і вроджена імунна відповідь, що передбачає важливу роль вродженої імунної системи (Zeng et al., 2016).

Також вважається, що собачий атопічний дерматит (ALD) пов'язаний з харчовою алергією, особливо з лімфоцитами. Науковці довели, що найбільш поширеним харчовим алергеном була соя, в той час як алергеном, що викликає найменшу кількість реакцій, був сом. Однак значну частину алергічних дерматитів можна пов'язати із атопією, алергією на укуси бліх, гіперчутливістю до кишкових паразитів, саркоптозом і грибковими та бактеріальними інфекціями. Ці прояви дуже схожі на харчову алергію або можуть бути взаємопов'язані. Крім того лікування хімічними засобами собак від блох та кліщів може викликати контактну алергію та неспецифічну імунну реакцію (Szabó et al., 2014).

Також клінічне дослідження собак, у яких діагностована харчова гіперчутливість після обмеження і провокації в їжі, виявило реакції гіперчутливості опосередковані лімфоцитами у 70 \% собак. У собак із хронічним дерматитом і підозрою на харчову гіперчутливість, спостерігали аналогічні симптоми. Крім того, дослідження, проведене на собаках з шлунково-кишковими захворюваннями, виявило, що периферичні лімфоцити реагують як мінімум на один харчовий антиген у всіх тварин (Pfister \& Armstrong, 2016).

За результатами проведеного моніторингу дерматитів у собак різної етіології були встановлені основні групи алергічних дерматитів (Suto et al., 2015)., які займають найбільший відсоток серед пацієнтів ветеринарної клініки. Доведена тенденція асоційованих випадків захворювань у собак, пов'язаних із хронічною патологією та особливостями вродженої імунної відповіді.

Висновки 3 проведеного дослідження і перспективи подальших розвідок у цьому напрямку.

1. При проведенні моніторингу дерматитів у собак було встановлено, що алергічні дерматити складали $63,01 \%$ випадків; паразитарні - 24,66 \%, грибкові 9,32 \% та бактеріальні 3,01\%.

2. Найбільш складні у діагностуванні та лікуванні атопічний, контактний та алергічний дерматити.

Перспектива подальшого дослідження: Проведення диференційної діагностики та розробка сучасних патогенетичних методів терапії за алергічних дерматитів у собак.

\section{References}

1. Pfister, K., \& Armstrong, R. (2016). Systemically and cutaneously distributed ectoparasiticides: a review of the efficacy against ticks and fleas on dogs. Parasites \& vectors, 9(1), 436. https://doi.org/10.1186/s13071-016-1719-7

2. Marchiondo, A. A., Holdsworth, P. A., Fourie, L. J., Rugg, D., Hellmann, K., Snyder, D. E., Dryden, M. W., \& World Association for the Advancement of Veterinary Parasitology (2013). World Association for the Advancement of Veterinary Parasitology (W.A.A.V.P.) second edition: guidelines for evaluating the efficacy of parasiticides for the treatment, prevention and control of flea and tick infestations on dogs and cats. Veterinary parasitology, 194(1), 84-97. https://doi.org/10.1016/j. vetpar.2013.02.003

3. Taenzler, J., de Vos, C., Roepke, R. K., Frénais, R., \& Heckeroth, A. R. (2017). Efficacy of fluralaner against Otodectes cynotis infestations in dogs and cats. Parasites \& vectors, 10(1), 30. https://doi.org/10.1186/s13071-016-1954-y

4. Nashat, M. A., Ricart Arbona, R. J., Riedel, E. R., Francino, O., Ferrer, L., Luchins, K. R., \& Lipman, N. S. (2018). Comparison of Diagnostic Methods and Sampling Sites for the Detection of Demodex musculi. Journal of the American Association for Laboratory Animal Science : JAALAS, 57(2), 173-185.

5. Shannon, J. G., Bosio, C. F., \& Hinnebusch, B. J. (2015). Dermal neutrophil, macrophage and dendritic cell responses to Yersinia pestis transmitted by fleas. PLoS pathogens, 11(3), e1004734. https://doi.org/10.1371/journal.ppat.1004734

6. Schwingen, J., Kaplan, M., \& Kurschus, F. C. (2020). Review-Current Concepts in Inflammatory Skin Diseases Evolved by Transcriptome Analysis: In-Depth Analysis of Atopic Dermatitis and Psoriasis. International journal of molecular sciences, 21(3), 699. https://doi.org/10.3390/ijms21030699

7. Bizikova, P., \& Olivry, T. (2016). A randomized, double-blinded crossover trial testing the benefit of two hydrolysed poultry-based commercial diets for dogs with spontaneous pruritic chicken allergy. Veterinary dermatology, 27(4), $289-\mathrm{e} 70$. https://doi.org/10.1111/vde.12302

8. Olivry, T., Bexley, J., \& Mougeot, I. (2017). Extensive protein hydrolyzation is indispensable to prevent IgE-mediated poultry allergen recognition in dogs and cats. BMC veterinary research, 13(1), 251. https://doi.org/10.1186/s12917-017-1183-4 
9. Masuda, K., Sato, A., Tanaka, A., \& Kumagai, A. (2020). Hydrolyzed diets may stimulate food-reactive lymphocytes in dogs. The Journal of veterinary medical science, 82(2), 177-183. https://doi.org/10.1292/jvms.19-0222

10. Kwon, B., Hong, S. Y., Kim, E. Y., Kim, J. H., Kim, M., Park, J. H., Sohn, Y., \& Jung, H. S. (2021). Effect of Cone of Pinus densiflora on DNCB-Induced Allergic Contact Dermatitis-Like Skin Lesion in Balb/c Mice. Nutrients, 13(3), 839. https:/l doi.org/10.3390/nu13030839

11. Nakaminami, H., Okamura, Y., Tanaka, S., Wajima, T., Murayama, N., \& Noguchi, N. (2021). Prevalence of antimicrobial-resistant staphylococci in nares and affected sites of pet dogs with superficial pyoderma. The Journal of veterinary medical science, 83(2), 214-219. https://doi.org/10.1292/jvms.20-0439

12. Mucha, S., Baurecht, H., Novak, N., Rodríguez, E., Bej, S., Mayr, G., Emmert, H., Stölzl, D., Gerdes, S., Jung, E. S., Degenhardt, F., Hübenthal, M., Ellinghaus, E., Kässens, J. C., Wienbrandt, L., Lieb, W., Müller-Nurasyid, M., Hotze, M., Dand, N., Grosche, S., ... Ellinghaus, D. (2020). Protein-coding variants contribute to the risk of atopic dermatitis and skin-specific gene expression. The Journal of allergy and clinical immunology, 145(4), 1208-1218. https://doi.org/10.1016/j. jaci.2019.10.030

13. Norsgaard, H., Svensson, L., Hagedorn, P. H., Moller, K., Olsen, G. M., \& Labuda, T. (2012). Translating clinical activity and gene expression signatures of etanercept and ciclosporin to the psoriasis xenograft SCID mouse model. The British journal of dermatology, 166(3), 649-652. https://doi.org/10.1111/j.1365-2133.2011.10713.x

14. Swindell, W. R., Johnston, A., Xing, X., Voorhees, J. J., Elder, J. T., \& Gudjonsson, J. E. (2013). Modulation of epidermal transcription circuits in psoriasis: new links between inflammation and hyperproliferation. PloS one, 8(11), e79253. https://doi.org/10.1371/journal.pone.0079253

15. Zeng, X., Zhao, J., Wu, X., Shi, H., Liu, W., Cui, B., Yang, L., Ding, X., \& Song, P. (2016). PageRank analysis reveals topologically expressed genes correspond to psoriasis and their functions are associated with apoptosis resistance. Molecular medicine reports, 13(5), 3969-3976. https://doi.org/10.3892/mmr.2016.4999

16. Szabó, K., Bata-Csörgö, Z., Dallos, A., Bebes, A., Francziszti, L., Dobozy, A., Kemény, L., \& Széll, M. (2014). Regulatory networks contributing to psoriasis susceptibility. Acta dermato-venereologica, 94(4), 380-385. https://doi.org/10.2340/00015555-1708

17. Pfister, K., \& Armstrong, R. (2016). Systemically and cutaneously distributed ectoparasiticides: a review of the efficacy against ticks and fleas on dogs. Parasites \& vectors, 9(1), 436. https://doi.org/10.1186/s13071-016-1719-7

18. Suto, A., Suto, Y., Onohara, N., Tomizawa, Y., Yamamoto-Sugawara, Y., Okayama, T., \& Masuda, K. (2015). Food allergens inducing a lymphocyte-mediated immunological reaction in canine atopic-like dermatitis. The Journal of veterinary medical science, 77(2), 251-254. https://doi.org/10.1292/jvms.14-0406

\section{Olga Stotska, postgraduate student, Sumy National Agrarian University, Sumy, Ukraine}

Monitoring of dog dermatitis in the conditions of private veterinary clinic "Alfa-vet", Konotop town

the incidence of dermatitis in dogs of polyetiological origin was monitored in the work. Dermatitis is a general definition for any type of skin inflammation. This term is usually used to describe the condition of the skin before reaching a specific diagnosis. There are many causes of skin inflammation, including external irritants, burns, allergens, injuries and infections (bacterial, viral, parasitic or fungal). Dermatitis can also be associated with diseases of the internal organs.

The studies were conducted on the basis of "Alpha -vet" veterinary medicine clinic (town Konotop, Krasnogirskaya 4a St.) in the period from 2020 to 2021. Patients were dermatitis dogs of different ages and genders. There were breeds Pug, Terrier, Labrador, Staffordshire Terrier, German Shepherd, Sharpei, Dachshund, French Bulldog and others. A total of 676 dogs were clinically examined during this period. The diagnosis was considered the anamnesis data, clinical signs, results of microscopic researches, clinical and biochemical indicators of blood, cytological researches. Statistical analysis was performed on the following indicators: seasonality, breed susceptibility to the disease, age and sex.

There are 730 cases of dermatitis of different origins were analyzed. Sarcoptic dermatitis was reported in six cases in which, in addition to sarcoptic mites, neutrophils, macrophages and plasma cells and keratinized epithelial cells were also observed. Hematology revealed relative neutrophilia and mild eosinophilia. Severe and generalized demodicosis complicated by bacteria and Malassezia sp. were recorded in 28 cases of infection. Histopathologically, ticks of the genus Demodex sp. at different stages of maturation, which damage the hair follicles along with concomitant pathological changes and foreign body granulomas. In addition, allergic flea dermatitis was also observed in 89 dogs. Cytology was clearly effective in the diagnosis of parasitic dermatitis.

There are 18 cases of atopic dermatitis in dogs were registered. However, the emergence of new cases is constantly growing. The pathogenetic mechanisms have not been fully studied, but numerous gene abnormalities and altered immunological processes are involved. The diagnosis of atopic dermatitis in dogs is based on antrcedent anamnesis, clinical examination and differential diagnosis. Allergic and bacterial are the main part of the dogs diseases.

The aim of the work is to monitor different types of dermatitis in dogs over the last year, including knowledge about the prevalence, diagnosis, new treatment options and difficulties in overcoming the disease.

It was found that allergic dermatitis accounted for $41,2 \%$ of cases; parasitic dermatitis is about $14 \%$, bacterial and fungal are $12 \%$ of the total number of cases. The most difficult to diagnose and treat are atopic, contact and allergic dermatitis.

Key words: Dermatitis, Sarcoptosis, Demodicosis, cytology, Atopic Dermatitis, allergy. 